\title{
7
}

\section{Modeling Rain Garden LID Impacts on Sewer Overflows}

\author{
Uzair (Sam) M. Shamsi
}

In September 2010, the U.S. Environmental Protection Agency (USEPA) released a new version (5.0.021) of Storm Water Management Model Version 5 (SWMM5) that offers low impact development (LID) modeling capability for the first time. The same LID modeling capability was soon enabled in the PCSWMM software (Version 2010, from Computational Hydraulic Int.). Five types of LIDs can be modeled in SWMM5 and PCSWMM: bioretention cells (rain gardens), infiltration trenches, porous pavement, cisterns (rain barrels) and vegetative swales. Using these new software releases and real world examples, this chapter presents some LID modeling features of SWMM5 and PCSWMM, input data requirements, modeling procedures, and output results for quantifying the LID impacts on sewer overflows. The modeling results presented here can help quantify the LID impacts on sewer overflows and allow sustainable developers to answer questions such as How much rainfall can be captured in a typical design year using a certain type of LID? or How many rain gardens are needed in a sewershed to capture a certain volume of storm water? A predictive model is presented to calculate the optimal number of rain gardens to achieve a target level of sewer overflow control.

\subsection{Introduction}

Sustainability requires meeting the needs of today without sacrificing the needs of tomorrow. In the context of combined sewer overflows (CSO) and sanitary sewer overflows (SSO), sustainability requires the elimination or reduction of sewer overflows to let future generations enjoy the waterways for designated

Shamsi, U.M. 2012. "Modeling Rain Garden LID Impacts on Sewer Overflows." Journal of Water Management Modeling R245-07. doi: 10.14796/JWMM.R245-07.

C CHI 2012 www.chijournal.org ISSN: 2292-6062 (Formerly in On Modeling Urban Water Systems. ISBN: 978-0-9808853-7-8) 
uses such as fishing or swimming. Stormwater LID controls are sustainable development practices designed to capture surface runoff using some combination of detention, infiltration and evapotranspiration.

Sustainable, or green, stormwater infrastructure uses LID controls such as rain gardens (bioretention cells), green roofs, infiltration trenches, porous pavement, cisterns (rain barrels) and vegetative swales. It is designed to capture surface runoff close to its source at distributed (decentralized) locations using some combination of detention, infiltration and evapotranspiration (Shamsi, 2009; Shamsi, 2010; Michael Baker Corporation, 2008).

Stormwater and wastewater utilities have started to embrace the use of LID controls as a viable means of managing stormwater runoff from existing and new developments. However, the benefits that this type of infrastructure gives in the reduction of CSO and SSO is not well understood and has been often overlooked. Engineers have started to evaluate the following benefits of stormwater LIDs:

preventing stormwater runoff from over $90 \%$ of storm events from entering the sewer collection system;

- eliminating sewer overflows resulting from smaller and more frequent rainfall events;

extenuating runoff so that peak flow rates are lowered, which should reduce the occurrence of the larger and less frequent rainfall induced sewer overflow events; and

improving the quality of stormwater runoff.

The extent of these benefits, however, depends on local conditions such as climate, soils and impervious land. Hydrologic and hydraulic modeling can be used to verify and quantify green infrastructure benefits and to design appropriate LID controls (Shamsi, 2011a; 2011b; Behr and Montalto, 2008).

\subsection{LID Modeling Approaches}

The following two types of modeling approaches are possible for modeling LIDs (Shamsi, 2011a; 2011b).

Single event simulation models compute the storm water runoff hydrograph from a discrete rainfall event hyetograph (e.g. 2 y or $24 \mathrm{~h}$ design storm). Infiltration and evaporation losses are calculated, but due to the short simulation time and lack of information about previous rainfall events, accurate antecedent soil moisture is not accounted for. The modeling results, therefore, are not reliable. These models generally require hourly rainfall data for the event. These models are easy to create and can complete a simulation run in few minutes. 
Continuous simulation models compute the storm water runoff from a continuous rainfall time series, such as hourly rainfall data for an entire year. Infiltration and evaporation losses calculated from previous rainfall events are used to accurately account for antecedent soil moisture and to determine the infiltration capacity available for the next storm. These models generally require hourly rainfall data and daily climatologic (evaporation, temperature and wind speed) data for an extended period of time. These models are relatively more expensive to create and run but provide better results for modeling LIDs due to the continuous nature of their evaporation and soil moisture accounting.

\subsection{LID Modeling Software}

Some of the computer programs that can be used for modeling LIDs for reducing sewer overflow volume and peak flow rate are:

SWMM5 version 5.0.021 (September 2010) or later (USEPA);

- PCSWMM 2011 (Computational Hydraulic Int., Guelph, Ontario, Canada);

- RECARGA (University of Wisconsin, Madison, Wisconsin);

- SUSTAIN (System for urban stormwater treatment and analysis integration, a GIS based LID siting tool, USEPA); and

- Source Loading and Management Model for Windows (WinSLAMM) (University of Alabama, Tuscaloosa, Alabama).

The main focus of this chapter is to demonstrate some LID modeling features and results of SWMM5 and PCSWMM using a case study. Both SWMM5 and PCSWMM models were created for the study area for comparison purposes. In the following figures, input data examples are from SWMM5 and output result examples are from PCSWMM.

\subsection{LID Modeling Features of SWMM5 5.0.021}

In SWMM5 and PCSWMM, LID controls are considered as properties of a given subcatchment, similar to how aquifers and snow packs are treated. SWMM can explicitly model five different generic types of LID controls (USEPA, 2010; CHI, 2011; Rossman, 2010):

1. Bioretention cells are depressions that contain vegetation grown in an engineered soil mixture placed above a gravel drainage bed. They provide storage, infiltration and evaporation of both direct rainfall and runoff captured from surrounding areas. Rain gardens, street planters, and green roofs (Chen and Li, 2011) are all variations of bioretention cells; 
2. Infiltration trenches are narrow ditches filled with gravel that intercept runoff from upslope impervious areas. They provide storage volume and additional time for captured runoff to infiltrate the native soil below;

3. Porous pavement systems are excavated areas filled with gravel and paved over with a porous concrete or asphalt mix. Normally all rainfall will immediately pass through the pavement into the gravel storage layer below it where it can infiltrate at natural rates into the site's native soil;

4. Rain barrels (or cisterns) are containers that collect roof runoff during storm events and can either release or re-use the rainwater during dry periods; and

5. Vegetative swales are channels or depressed areas with sloping sides covered with grass and other vegetation. They slow down the conveyance of collected runoff and allow it more time to infiltrate the native soil beneath it.

Although some LID controls can also provide significant pollutant reduction benefits, at this time SWMM5 only models their hydrologic performance. During a simulation SWMM5 performs a moisture balance that keeps track of how much water moves between LID layers and how much is stored within each layer.

When a user adds a specific type of LID control object to a SWMM5 project the LID Control Editor, shown in Figure 7.1, is used to set the design properties of each relevant layer (such as thickness, void volume, hydraulic conductivity and underdrain characteristics). The LID Usage Editor, shown in Figure 7.2, is invoked from a subcatchment's LID Control Editor to specify how a particular LID control will be deployed within the subcatchment.

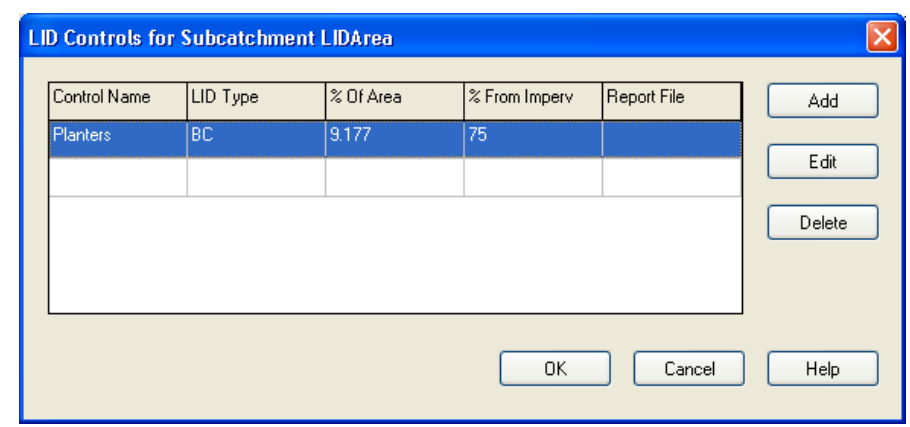

Figure 7.1 LID Controls Editor in SWMM5 (based on the case study data presented in section 7.6). 


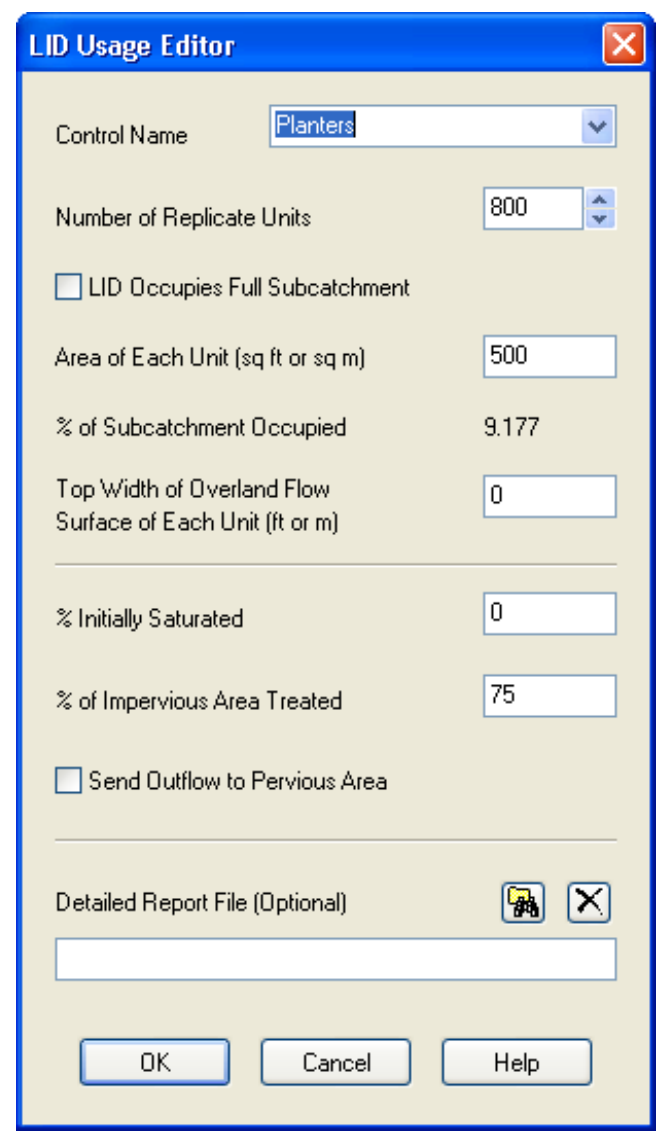

Figure 7.2 LID Usage Editor in SWMM5 (based on the case study data presented in section 7.6).

\subsection{LID Modeling Steps Using SWMM5 or PCSWMM}

The following steps can be taken for LID modeling using the continuous simulation approach. These steps are based on author's own experience from the case study described in the next section.

1. Obtain observed or historical rainfall, climatologic (for continuous modeling) and flow data;

2. Obtain soil type and infiltration data;

3. Divide the study area (e.g. a watershed or basin) in smaller units (e.g. subcatchments, subareas or subbasins); 
4. Obtain subcatchment dry weather flow time series data from flow monitors (if available) or estimate subarea dry weather flow and diurnal patterns using population or dwelling units;

5. Estimate subcatchment hydrologic properties (area, slope, percent imperviousness, overland flow width, surface roughness and runoff curve number) from paper maps, CAD or GIS;

6. From sewer system drawings, CAD or GIS determine pipe outfall size, length and invert elevation; manhole top and bottom elevation; and diversion chamber weir elevation and orifice opening size;

7. Input all data from previous steps to create a pre-LID model representing existing (gray) conditions;

8. Calibrate the pre-LID model using observed data from rain gauges and flow monitors, if available;

9. Run the calibrated pre-LID model with typical design year rainfall and climatologic data and save the output results;

10. Add desired LIDs to the pre-LID model to create a post-LID model representing improved (green) conditions;

11. Run the post-LID model with the same rainfall used in the preLID model and save the output results;

12. Repeat steps 10 and 11 with various combinations of LID types and sizes until the desired level of control (e.g. 85\% CSO volume capture or $4 \mathrm{CSOs}$ /year) is achieved; and

13. Compare the output results from the pre- and post-LID models to calculate the reduction in the number of overflow events, overflow volume, and peak overflow rate.

\subsection{Case Study}

To demonstrate the proposed LID modeling application for designing green infrastructure solutions, a SWMM5 continuous simulation model was created for the 100 acre (40.5 ha) combined sewer area in southwestern Pennsylvania shown in Figure 7.3. This case study area is part of a larger 3000 acre (1 214 ha) combined and sanitary sewer service area. The service area model was calibrated and verified for the baseline conditions (i.e. before adding any LIDs). Observed data for model calibration and verification was collected from 25 automatic flow monitors (with pressure and velocity sensors) and three rain gauges installed throughout the service are for the period from March to September 2009.

The pre-LID model had the following parameters:

Annual rainfall total $=32.4 \mathrm{in} .(82.3 \mathrm{~cm})($ typical year 2005$)$; 
- $\quad$ Drainage area $=100$ acre $(40.5 \mathrm{ha})$

- Impervious land surface $=50 \%$;

- $\quad$ CSO outfall pipe diameter $=4.5 \mathrm{ft}(1.37 \mathrm{~m})$; and

- Green-Ampt soil parameters $=6.7$ in. $(17.02 \mathrm{~cm})$ suction head, $0.26 \mathrm{in} . / \mathrm{h}(0.66 \mathrm{~cm} / \mathrm{h})$ conductivity, 0.17 initial deficit for silt loam soils with a hydrologic soil group of $\mathrm{B} / \mathrm{C}$.

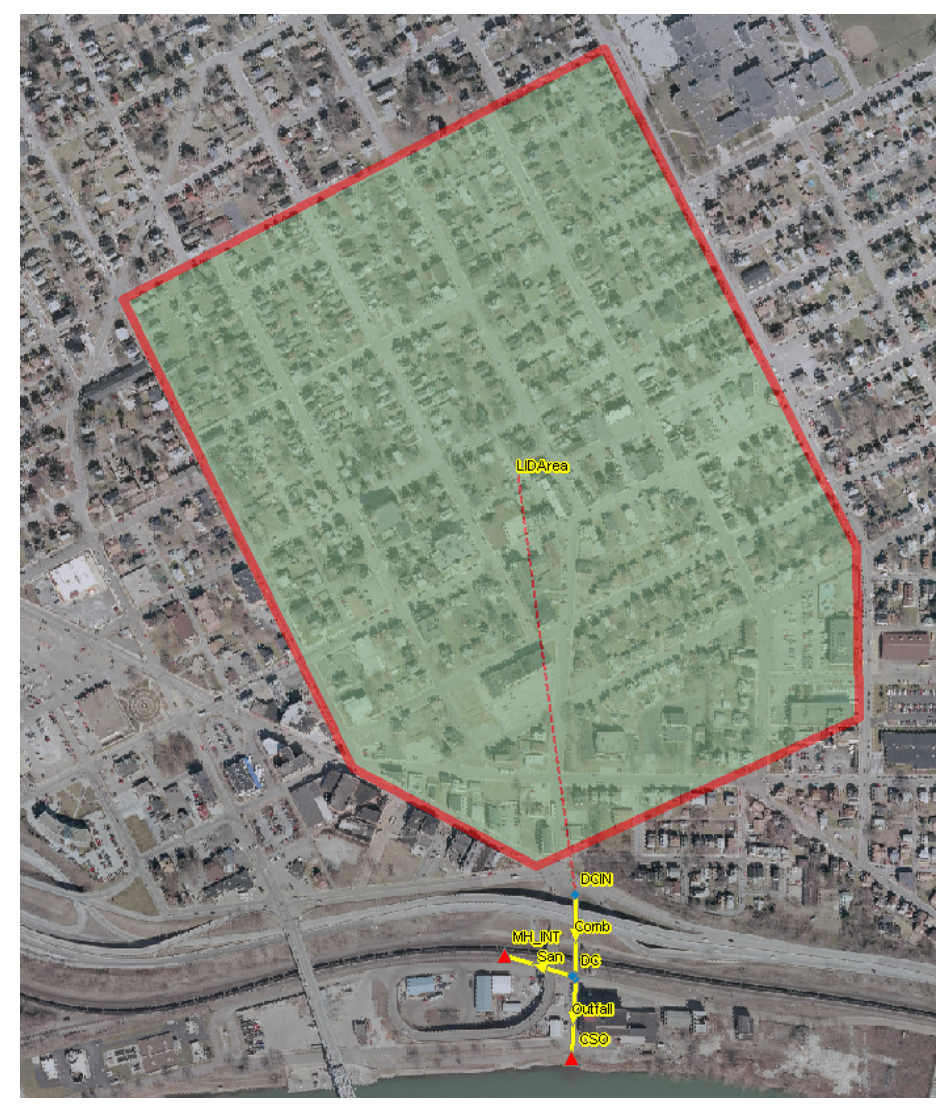

Figure 7.3 Study area map.

The number of CSO events was computed using an inter-event duration of $24 \mathrm{~h}$. This duration was calculated from the $15 \mathrm{~min}$ rainfall data for the entire typical year of 2005 using the Statistics function of SWMM5. Various durations were analyzed iteratively. The $24 \mathrm{~h}$ duration that produced a coefficient of variation (standard deviation/mean) of approximately 1.0 was selected as the final inter-event duration. Results of inter-event duration analysis are shown in Figure 7.4. 


\begin{tabular}{r|r|r|r|r|r|r|}
\hline \multicolumn{1}{c|}{$\begin{array}{c}\text { Inter Event } \\
\text { Duration }\end{array}$} & Mean & St. Dev & \# Events & COV (SD/Mean) & $\begin{array}{c}\text { Event Threshold } \\
\text { (Precipitation) }\end{array}$ & $\begin{array}{c}\text { Event Threshold } \\
\text { (Event Volume) }\end{array}$ \\
\hline 12 & 0.46 & 0.45 & 63 & 0.98 & 0.025 & 0.1 \\
\hline 24 & 0.54 & 0.53 & 54 & 0.99 & 0.025 & 0.1 \\
\hline 48 & 0.68 & 0.77 & 43 & 1.14 & 0.025 & 0.1 \\
\hline
\end{tabular}

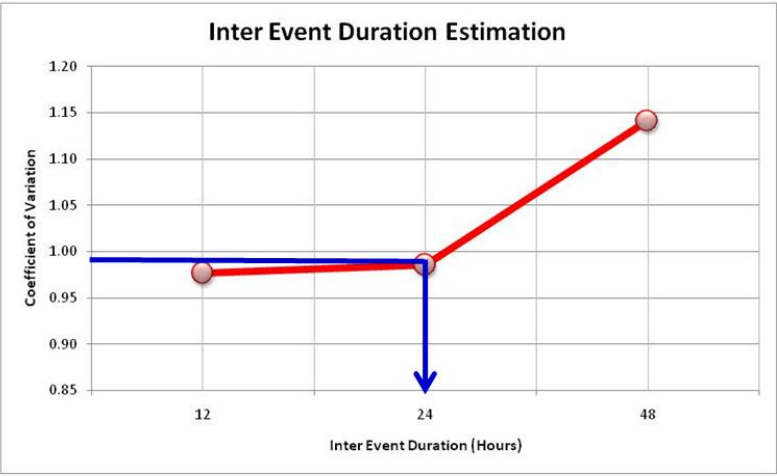

Figure 7.4 Inter-event duration estimation.

The pre-LID model provided the following CSO results:

- $\quad$ Number of CSO events $=45$;

- Peak CSO flow rate $=25.73 \mathrm{MGD}\left(1.13 \mathrm{~m}^{3} / \mathrm{s}\right)$; and

- $\quad$ CSO overflow volume $=14.93 \mathrm{MG}\left(0.65 \mathrm{~m}^{3} / \mathrm{s}\right)$.

The PCSWMM results for the existing (pre-LID) conditions for the entire typical year are shown in Figure 7.5. The top chart shows the input rainfall hyetograph. The bottom chart shows the CSO outfall hydrograph.

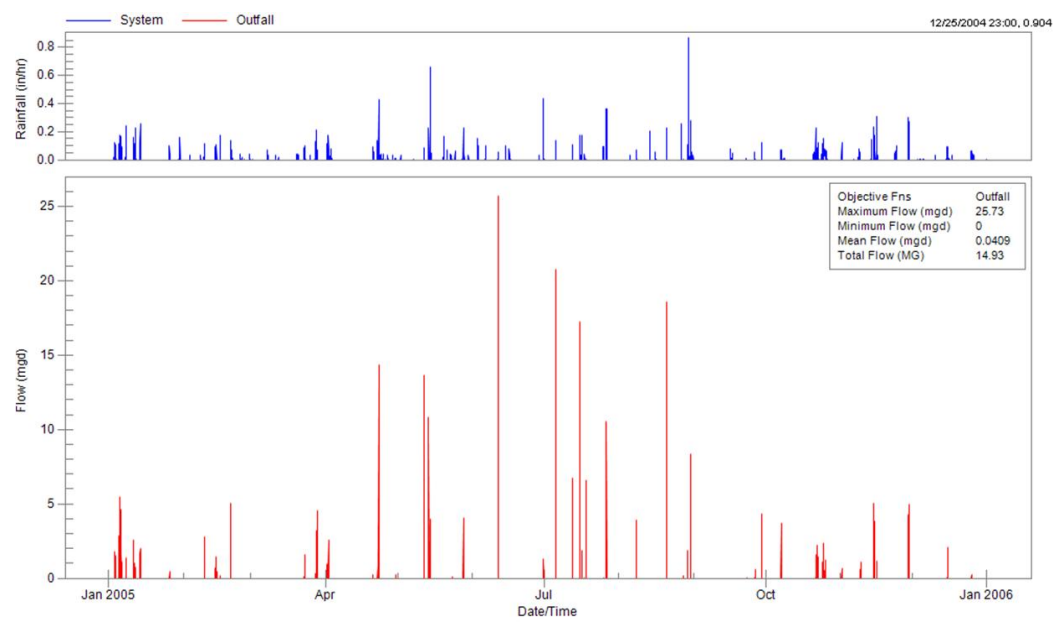

Figure 7.5 Pre-LID PCSWMM results. 
The initial post-LID model included ten rain gardens $(0.1$ units/acre, 0.25 units/ha) with the following properties:

Area $=500 \mathrm{ft}^{2}\left(46.45 \mathrm{~m}^{2}\right)$;

Vegetative cover $=90 \%$;

Soil layer $=18$ in. $(45.7 \mathrm{~cm})$;

- $\quad$ Soil porosity $=0.5$;

- Soil conductivity $=0.5 \mathrm{in} . / \mathrm{h}(1.3 \mathrm{~cm} / \mathrm{h})$;

- Gravel layer $=12$ in. $(30.5 \mathrm{~cm})$;

- $\quad$ Gravel void ratio $=0.83$;

- Gravel conductivity $=10$ in. $/ \mathrm{h}(25.4 \mathrm{~cm} / \mathrm{h})$; and

- Underdrain exponent $=0.5$.

It provided the following $\mathrm{CSO}$ results:

Number of CSO events $=44$;

- Peak CSO flow rate $=24.15 \mathrm{MGD}\left(1.06 \mathrm{~m}^{3} / \mathrm{s}\right)$;

- CSO overflow volume $=14.41 \mathrm{MG}\left(0.63 \mathrm{~m}^{3} / \mathrm{s}\right)$; and

- Percent capture of CSO volume $=3.5 \%$.

Obviously, 0.1 units/acre ( 0.25 units/ha) reduced the CSO events marginally with only a $3.5 \%$ annual CSO volume capture. To achieve a target $85 \%$ capture, the number of rain gardens was increased incrementally. The optimal number of rain gardens was 800 or 8 units/acre (20 units/ha). The final post-LID model corresponding to 8 units/acre (20 units/ha) provided the following CSO results:

Number of CSO events $=16$;

- $\quad$ Peak CSO flow rate $=13.01 \mathrm{MGD}\left(0.57 \mathrm{~m}^{3} / \mathrm{s}\right)$;

- CSO overflow volume $=2.16 \mathrm{MG}\left(0.09 \mathrm{~m}^{3} / \mathrm{s}\right)$; and

- Percent capture of CSO volume $=85.5 \%$.

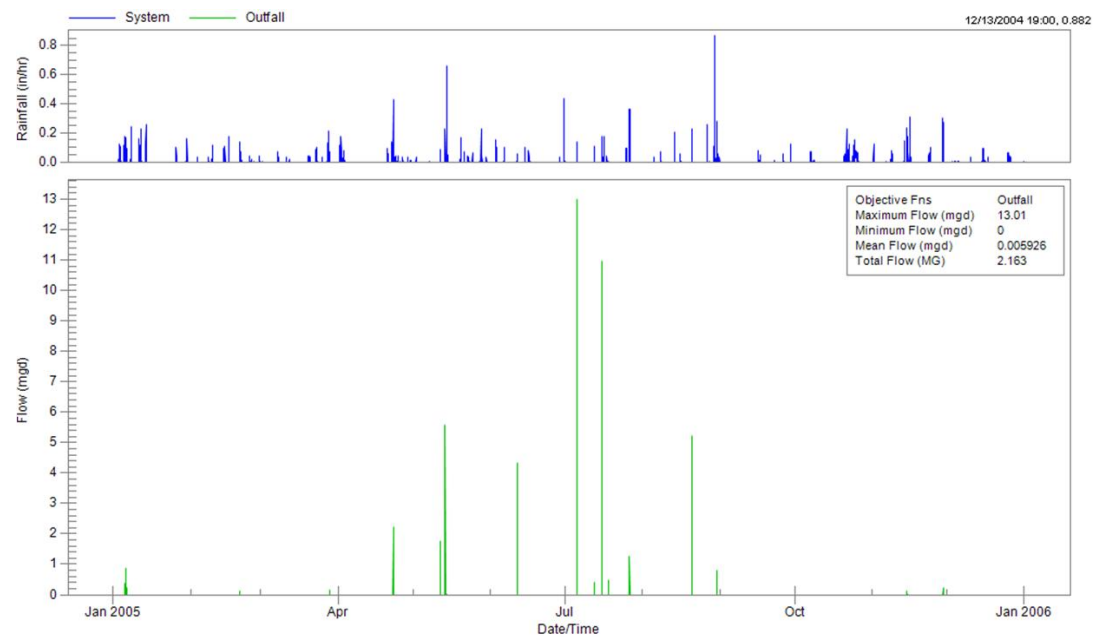

Figure 7.6 Post-LID PCSWMM results. 
The PCSWMM model output CSO outfall results for the green (post-LID) conditions for the typical year are shown in Figure 7.6. A comparison of Figures 7.5 and 7.6 clearly shows the reduction in CSO volume, peak flow and frequency.

The PCSWMM LID results for the typical year are shown in Figure 7.7. The input rainfall hyetograph and outfall hydrographs shown in this figure allow users to understand the continuous nature of rain garden operation and performance. For example, soil infiltration and evapotranspiration are higher during summer months due to high temperatures and unsaturated soil.

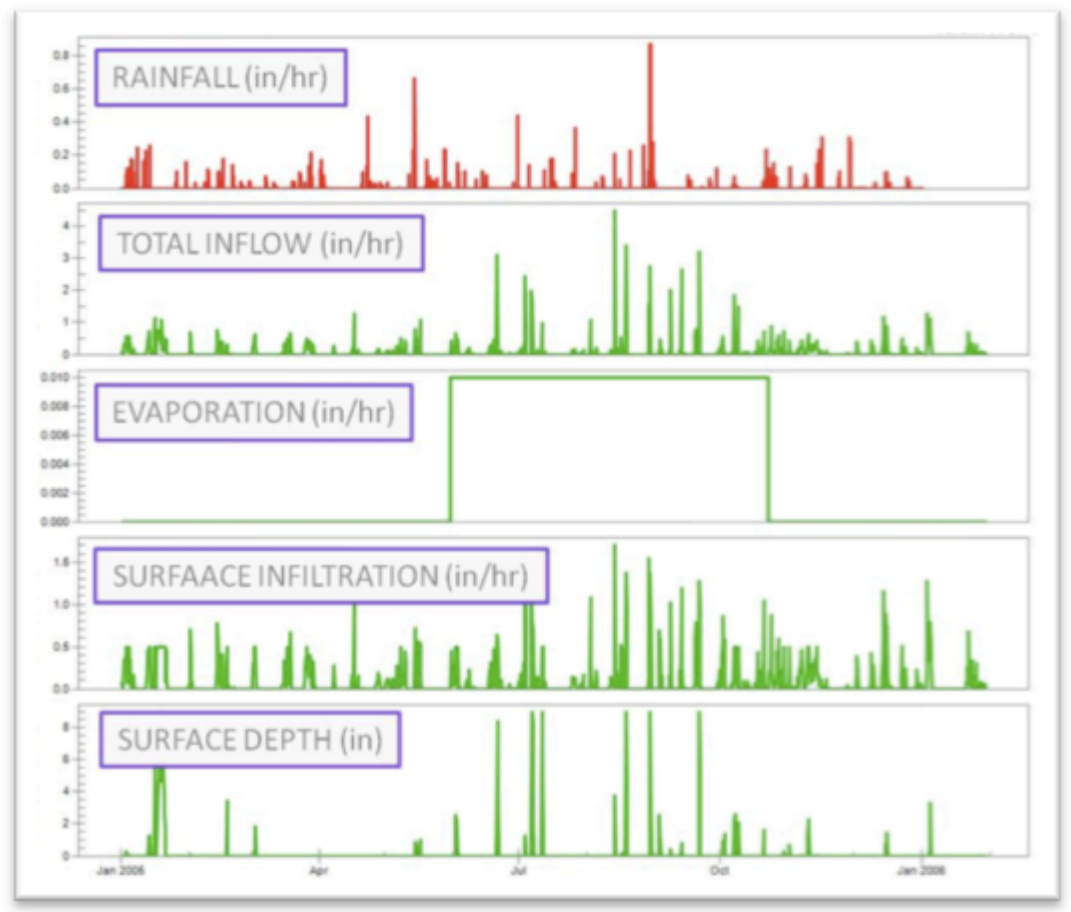

Figure 7.7 PCSWMM LID hydrographs.

Figure 7.8 shows the modeled relationship between the number of rain gardens and the percentage reduction in CSO volume. For example, one would need to construct 8 rain gardens per acre (20/ha) to reduce the CSO volume by $85 \%$. For small 0.125 acre $\left(505.86 \mathrm{~m}^{2}\right)$ urban residential lots, this would require constructing a rain garden for almost every house, which might not be feasible. Therefore, the required number of rain gardens to reduce CSO volume substantially may be large in certain types of climates and soils. The trendline in Figure 
7.8 has an $R^{2}$ value of $99.7 \%$, which represents an excellent goodness of fit indicator to the model results. The corresponding predictive formula to calculate the required number of rain gardens to achieve a certain CSO volume reduction target is shown in Equation 7.1. Such predictive equations can be developed to estimate the optimal number of rain gardens for different climates, soils types, and land surface percent imperviousness.

$$
R G=22.3 T^{3}-16.4 T^{2}+6.9 T-0.04
$$

where:

$$
\begin{aligned}
R G & =\text { Number of rain gardens per acre, and } \\
T & =\text { Required CSO volume reduction target }(\%) .
\end{aligned}
$$

\begin{tabular}{|c|c|c|c|c|c|}
\hline \multicolumn{2}{|c|}{ No. of Rain Gardens } & \multicolumn{4}{|c|}{ Typical Year (2005) CSO Results } \\
\hline In 100 acres & Per acre & $\begin{array}{c}\text { Number of } \\
\text { Events }\end{array}$ & $\begin{array}{c}\text { Peak Flow } \\
\text { (MGD) }\end{array}$ & $\begin{array}{c}\text { Discharge } \\
\text { Volume (MG) }\end{array}$ & $\begin{array}{c}\text { CSO Vol. } \\
\text { Reduction (\%) }\end{array}$ \\
\hline 0 & 0 & 45 & 25.73 & 14.93 & $0.0 \%$ \\
\hline 10 & 0.1 & 44 & 24.15 & 14.41 & $3.5 \%$ \\
\hline 100 & 1.0 & 35 & 23.71 & 11.53 & $22.8 \%$ \\
\hline 500 & 5.0 & 16 & 17.39 & 3.75 & $74.9 \%$ \\
\hline 750 & 7.5 & 16 & 15.08 & 2.53 & $83.1 \%$ \\
\hline 800 & 8.0 & 16 & 13.01 & 2.16 & $85.5 \%$ \\
\hline 1000 & 10.0 & 16 & 4.2 & 1.04 & $93.0 \%$ \\
\hline
\end{tabular}

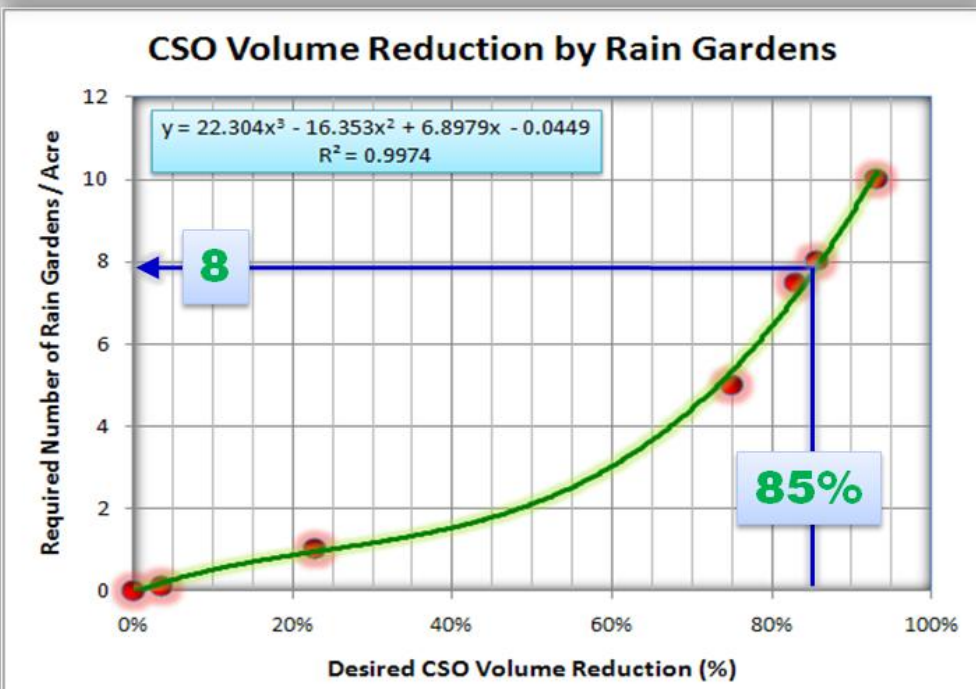

Figure 7.8 Percent capture vs number of rain gardens for $50 \%$ imperviouness. 


\subsection{Effect of Percent Imperviousness}

The chart in Figure 7.8 above reflects the study area percent imperviousness of $50 \%$. To illustrate the effect of sewershed percent imperviousness the model was rerun with different percent imperviousness values. Figure 7.9 shows the modeled relationship between the number of rain gardens and the percentage reduction in CSO volume if the percent imperviousness of the study area is increased to $75 \%$.

CSO Volume Reduction by Rain Gardens ( $\mathrm{PI}=75 \%$ )

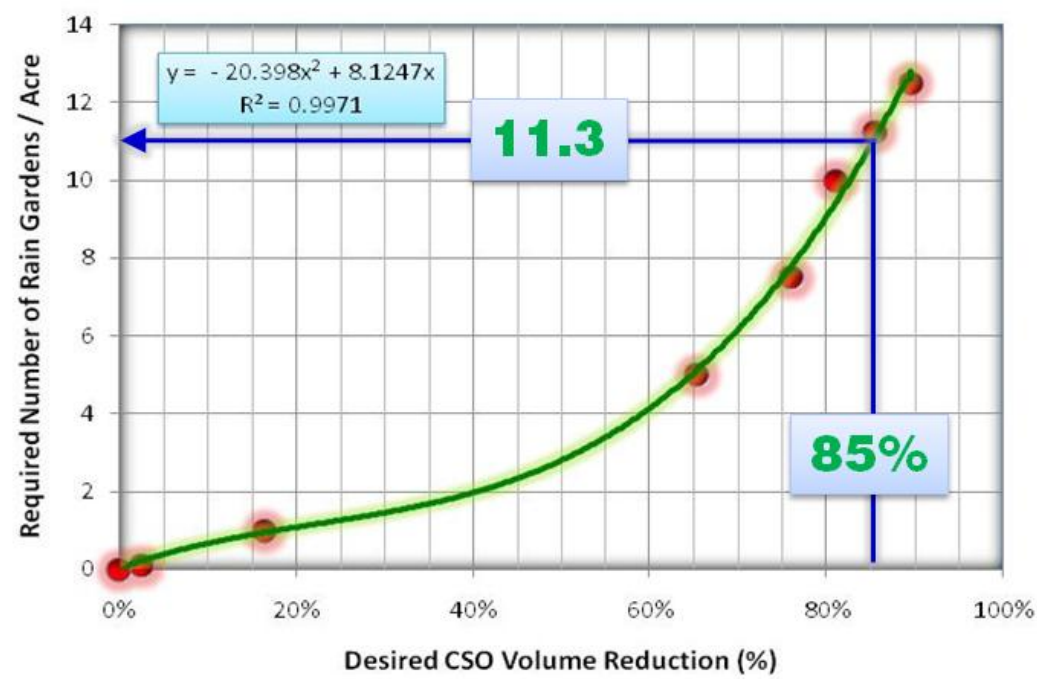

Figure 7.9 Percent capture vs number of rain gardens for $75 \%$ imperviouness.

The results indicate that a larger number of rain gardens will be needed for the same level of CSO control. For example, one would need to construct about 11 rain gardens per acre (27/ha) to reduce the CSO volume by $85 \%$. Likewise, when the percent imperviousness was reduced to $25 \%$, the results indicated that a smaller number of rain gardens would be needed for the same level of CSO control. For example, only 5 rain gardens per acre (12/ha) would be required to reduce the CSO volume by $85 \%$.

\subsection{Effect of Soil Types}

The existing model was based on the study area soil type of silt loam (hydrologic soil group $\mathrm{B} / \mathrm{C}$ ) with saturated hydraulic conductivity $(K)$ of $0.26 \mathrm{in} . / \mathrm{h}$ 
$(6.35 \mathrm{~mm} / \mathrm{h})$. Next, the effect of soil types was studied by rerunning the model with different Green-Ampt input parameters to reflect different types of native soils. The results are presented as a hydraulic conductivity sensitivity plot in Figure 7.10. It can be seen that for sandy loam soils (hydrologic soil group B, $K$ $=0.43 \mathrm{in} . / \mathrm{h}, 12 \mathrm{~mm} / \mathrm{h}$ ), there is no significant effect on the CSO peak and volume for the typical year. For loam soils (hydrologic soil group C, $K=0.13 \mathrm{in} . / \mathrm{h}, 3 \mathrm{~mm} / \mathrm{h}$ ), there was a $10 \%$ increase in CSO peak and volume. For clay soils (hydrologic soil group $\mathrm{D}, K=0.01 \mathrm{in} . / \mathrm{h}, 0.3 \mathrm{~mm} / \mathrm{h}$ ), there was a $25 \%$ increase in CSO peak and volume.

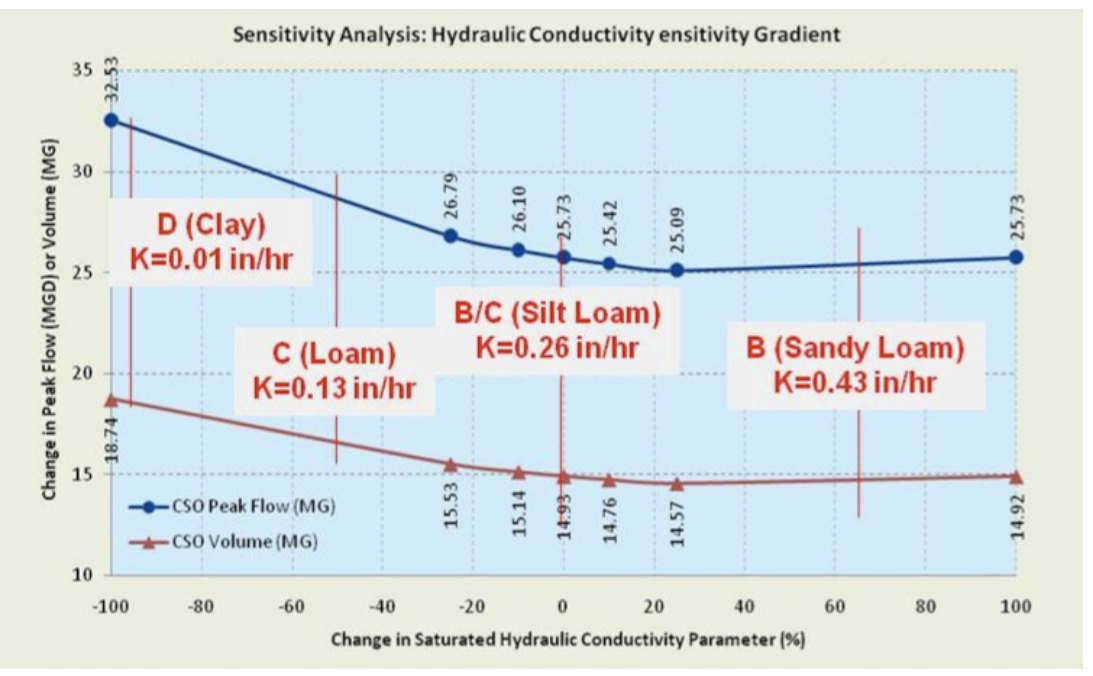

Figure 7.10 Soil type sensitivity plot.

\subsection{Conclusions}

From the case study results presented in this chapter it can be concluded that rain gardens can be used to substantially reduce sewer overflows. However, the required number of rain gardens for high $\mathrm{CSO}$ volume reduction may be large in certain types of climates and soils.

The SWMM5 or PCSWWM continuous simulation methods presented in this chapter can be used to determine the optimal number of rain gardens or other LID units for various types of drainage areas and CSO control targets.

Model results can be post-processed to develop easy to use predictive models to calculate the optimal numbers of LID controls to achieve a target level of $\mathrm{CSO}$ control for various types of drainage areas. 


\section{References}

Behr, C.T. and F.A. Montalto. 2008. Risk Analysis Application for Assessing the Costeffectiveness of Low Impact Development for CSO Control using LIDRA. 2008 International Low Impact Development Conference, American Society of Civil Engineers, Nov. 16-19, 2008. Seattle, WA.

Chen, J. and J. Li. 2011. "Characterization of Green Roof Stormwater Runoff Quality" Journal of Water Management Modeling R241-18. doi: 10.14796/JWMM.R241-18.

Computation Hydraulics Int. (CHI). 2011. User's Guide to SWMM. 13th Edition, CHI Press, Guelph, ON. www.chiwater.com

Shamsi, U.M. 2009. Green Stormwater Management for Sustainable Urban Infrastructure. 2009 Engineering Sustainability Conference, Pittsburgh, Pennsylvania, April 1921, 2009.

Shamsi, U.M. 2010. "Low Impact Development for Stormwater Quantity and Quality." Journal of Water Management Modeling R236-13. doi: 10.14796/JWMM.R236-13.

Shamsi, U.M. 2011a. Preventing Sewer Overflows Using Sustainable Infrastructure. 2011 Engineering Sustainability Conference, Pittsburgh, Pennsylvania, April 10-12, 2011.

Shamsi, U.M. 2011b. Modeling to Quantify the LID Benefits for CSO Reduction. 5th National Low Impact Development Conference, EWRI, Philadelphia, September 2528, 2011.

Michael Baker Corporation. 2008. From Capitol Hill to the Waterfront. Signature Magazine, Volume 2, Issue 1, 2008.

Rossman, L.A. 2010. "Modeling Low Impact Development Alternatives with SWMM." Journal of Water Management Modeling R236-11. doi: 10.14796/JWMM.R236-11.

U.S. Environmental Protection Agency (USEPA). 2010. Storm Water Management Model. Version 5.0.021. 